Огляди літератури, оригінальні дослідження, погляд на проблему, ювілеї

уДК 616.832.9-007.43-08-039.76-053.2

DOI 10.11603/1811-2471.2018.v0.i4.9736

\title{
СУЧАСНI АСПЕКТИ РЕАБІЛІТАЦІї ДІТЕЙ ІЗ SPINA BIFIDA
}

\author{
๑О. Р. Боярчук', К. Т. Глушко', Н. М. Свірська², В. В. Ковальов², О. Р. Шило² \\ ДВНЗ «Тернопільський державний медичний університет імені І. Я. Горбачевського Моз України»' \\ Тернопільська обласна дитяча клінічна лікарня²
}

PЕзЮМЕ. Спинномозкова грижа $є$ однією з найпоширеніших вроджених вад, що полягає у поєднаному ураженні органів і систем та спричиняє ранню постійну недієздатність і навіть смерть. Лікування та реабілітація дітей зі Spina bifida $\epsilon$ складним та довготривалим процесом, що потребує залучення та співпраці лікарів різних спеціальностей.

Метою нашої роботи було проаналізувати літературні дані щодо сучасних можливостей покращення якості життя дітей з розщілиною хребта. До найпоширеніших проблем у дітей з цією патологією належать обмеження чи повна відсутність рухливості, зниження шкірної чутливості та утворення ран і пролежнів, розвиток гідроцефалії, нейрогенні розлади сечового міхура та кишечника, що часто супроводжуються нетриманням сечі та випорожнень; у тяжких випадках спостерігаються когнітивні розлади. Обмеження чи відсутність фізичної активності призводить до ожиріння і пов'язаних із ним ускладнень. Забезпечення здатності самостійно пересуватися та покращення фізичної активності знижує ризик ожиріння та поліпшує соціальні контакти й якість життя. Реабілітація нейрогенних розладів сечового міхура забезпечується чистою періодичною катетеризацією, проведенням лікувальної фізкультури та фізіотерапії. Вправи лікувальної фізкультури спрямовані на зміцнення м'язів тазового дна. Різновид фізіотерапії залежить від виду нейрогенного сечового міхура. Одним і з ефективних методів корекції розладів сечовипускання $\epsilon$ метод біологічного зворотного зв'язку. Він у досить простий спосіб дозволяє навчити дитину координувати роботу м'язів тазового дна.

Висновок. Реабілітація дітей із spina bifida $\epsilon$ довготривалою і багатоцільовою роботою, яка у значній мірі залежить від стану дитини та потребує мультидисциплінарного ведення. Об'єднання зусиль лікарів та батьків, використання сучасних методів реабілітації можуть покращити якість життя дітей із spina bifida.

Пошук літератури здійснювався за допомогою баз даних PubMed та КиберЛенинка.

КлючовІ СлОВА: діти; spina bifida; реабілітація.

Вступ. Спинномозкова грижа, або spina bifida (SB), $\epsilon$ однією із найчастіших вроджених вад невральної трубки, яка трапляється із частотою від 3 до 12,8 випадків на 10000 новонароджених [1]. Це захворювання характеризується ураженням спинного, часто і головного мозку, що призводить до розладів рухової сфери, порушення чутливості, нетримання сечі та випорожнень, а в тяжких випадках - і до когнітивних розладів $[1,2]$. Згідно з даними Асоціації Spina Bifida, у Сполучених Штатах Америки SB $\epsilon$ найпоширенішим вродженим дефектом, що призводить до постійної недієздатності протягом життя [2, 3]. У зв'язку з удосконаленням методів лікування SB та їі ускладнень збільшується тривалість життя хворих дітей, але у багатьох із них спостерігається постійне обмеженняможливостей, щопотребуєміждисциплінарного догляду протягом усього життя $[4,5]$. Існує кілька типів SB, котрі по-різному впливають на повсякденне життя: SB oculta (закритий тип), менінгоцеле і мієломенінгоцеле (відкриті форми), причому останній тип SB $\epsilon$ найпоширенішим і найтяжчим за перебігом [1].

Лікування менінгомієлоцеле традиційно передбачає операцію протягом 48 годин після народження. Спинку дитини закривають для зниження до мінімуму ризику висхідної інфекції та розвитку менінгіту. На даний час у ряді центрів упро- ваджено раннє втручання (хірургія плода), що показує перспективні результати [6]. Подальший догляд передбачає спостереження за станом ЦНС, вимірювання обводу голівки дитини для оцінки швидкості її росту та необхідності шунтування [6]. Практично всі новонароджені з пошкодженням грудного відділу, близько 85 \% хворих із ураженням поперекового відділу та 70 \% з куприковим ураженням потребують проведення вентрикулоперитонеального шунтування. Радіологічно підтверджена аномалія Chiari II наявна в більшості дітей, проте клініка грижі ромбоподібного мозку може спостерігатися лише в 30 \% випадків. Вона проявляється у вигляді апное, розладів ковтання, стридору у новонародженої дитини, головним болем, квадрипарезом, сколіозом та проблемами балансу/координації у старших дітей [6].

Ортопедичні деформації, як правило, лікуються незабаром після народження і потребують тривалого спостереження. Функція нирок та сечового міхура контролюється за допомогою УЗД та уродинамічних досліджень для виявлення ускладнень внаслідок їх нейрогенної дисфункції. Наприклад, затримка сечі та міхурово-сечовідний рефлюкс призводять до рецидивуючих інфекцій сечовивідних шляхів та, як наслідок, до погіршення функції нирок. Терапія нейрогенного сечового міхура полягає в поєднанні чистої переривчастої 
Огляди літератури, оригінальні дослідження, погляд на проблему, ювілеї

катетеризації, фармакотерапії та оперативного втручання. Розлади кишечника не є проблемою у новонароджених, але діти старшого віку потребують корекції нейрогенного кишечника, включаючи застосування супозиторіїв, клізм або послаблювальних засобів та використання антеградних кишкових клізм [6].

У розвинутих країнах медичний догляд та спостереження за особами із SB найкращим чином забезпечується завдяки співпраці міждисциплінарної команди під керівництвом лікаря, який проводить тренінг з догляду за дітьми зі spina bifida, включаючи координатора, відповідального за спостереження хворих. Додатковими членами команди $є$ медсестра, яка спеціалізується на догляді за дітьми з різними вадами розвитку, дитячий нейрохірург, уролог, ортопедичний хірург, фізіотерапевт та соціальний працівник. Інші фахівці, наприклад психолог, можуть залучатися при необхідності в окремих випадках. Вирішальне значення має комунікація між членами спеціалізованої команди та лікарем первинної ланки, який забезпечує планову медичну допомогу, включаючи імунізацію та постійну емоційну підтримку сім'ї. Додаткові питання, які, можливо, доведеться вирішувати, включають нервово-поведінковий розвиток, рухливість та засоби пересування, підтримку ваги, догляд за шкірою та уникнення латексної сенсибілізації [6].

На підставі Міжнародної класифікації функціонування, обмеження життєдіяльності та здоров'я (МКФ) (англ. International Classification of Functioning, Disability and Health, ICF), SB-пов'язані розлади (нервово-м'язова слабкість, нейрогенний сечовий міхур чи кишечник, гідроцефалія, когнітивні порушення, кісткові або суглобові деформації, шкірна гіпостезія та виникнення ран) можуть спричинити обмеження "активності" (зниження рухливості, здатності до самообслуговування, когнітивних можливостей) та "взаємодії" (зайнятість, навчання, соціальна реінтеграція) [7]. Численні ускладнення спричинені різними процедурами, проведеними в дитинстві, такими як вентрикуло-перитонеальні шунти, урологічні втручання, ортопедична хірургія [7]. При прогресуванні хвороби виникають інші проблеми: ураження сечового міхура та нирок з розвитком ниркової недостатності, тетеринг синдром (або синдром фіксованого спинного мозку), сирінгомієлія, дегенеративні проблеми опорно-рухового апарату, остеопороз, серцево-легенева хвороба, ожиріння, латексна алергія та інші $[7,8]$, які спричиняють значні страждання і знижують якість життя.

Залежно від форми SB та рівня ураження спинного мозку, діти з SB можуть мати різного ступеня труднощі із пересуванням [9]. Рівень рух- ливості визначається згідно з класифікацією Хоффера, скоригованою Schoenmakers et al., і коливається від нормальної рухливості (рівень 1) до нездатності самостійно пересуватися (рівень 5) [9]. Обмеження рухливості має різноманітний негативний вплив на стан здоров'я дітей та дорослих із SB. Зокрема, внаслідок обмеження рухливості 3 віком у осіб з SB важливою проблемою стає розвиток ожиріння [3]. Необхідність підтримувати здоровий і активний спосіб життя у осіб з SB $є$ вищою, ніж у загальній популяції [3]. За даними дослідження Сrytzer T. М. та ін., дорослі з SB ведуть неактивний спосіб життя, мають нижчий рівень щоденної фізичної активності та аеробної здатності, вищу частоту ожиріння, низьку якість життя, порівняно з референтними групами [3]. Терапевтичні втручання зменшують біль, підвищують біомеханічну ефективність під час руху за допомогою інвалідних візків, а також поліпшують фізичну активність та баланс. Проте, у зв'язку з неправильним розподілом жирової тканини, короткою статурою, сколіозом та суглобовими контрактурами, звичайні нормативні дані не можуть використовуватися і потребують подальших досліджень [3].

Здатність до самостійної фізичної активності має також важливий психологічний та соціальний ефект. Зокрема, для багатьох дітей це $є$ важливим питанням, що не тільки позитивно впливає на стан здоров'я, а й покращує соціальні контакти. Самостійність, здатність самостійно пересуватися, контроль ваги, соціальні контакти є важливими аспектами, що забезпечують успішну реабілітацію та якість життя дітей із SB [10].

ще одним фактором, що впливає на якість життя пацієнтів із SB, є можливість залишатися «сухими». У значній мірі це забезпечується проведенням чистої переривчастої катетеризації; можна навчити дітей проводити її самостійно після 5-6 років і тим самим покращити їхню самостійність і соціалізацію.

Поширеними методами ребілітації нейрогенних розладів сечового міхура $є$ лікувальна фізкультура та фізіотерапія. Лікувальна фізкультура при нейрогенному сечовому міхурі включає проведення вправ для зміцнення м'язів малого таза, спини і живота [11]. Методика фізіотерапії залежить від виду нейрогенного сечового міхура. При гіпорефлекторній дисфункції використовують електростимуляцію, а при гіперефлекторній - теплові процедури на ділянку сечового міхура і поперековокрижову зону [11]. Окрім того, ефективними $\epsilon$ сегментарний масаж, рефлексотерапія [11].

У 1970-х роках минулого століття в Сполучених Штатах Америки почали використовувати метод біологічного зворотного зв'язку (БЗ3). Ця методика полягає в тому, що при свідомому відсте- 
Огляди літератури, оригінальні дослідження, погляд на проблему, ювілеї

женні несвідомих реакцій організму можна навчитися ними керувати. Ця методика $\epsilon$ неінвазивною, нетоксичною та ефективною, що особливо важливо при реабілітації дітей і широко використовується при розладах сечовипускання і акту дефекації. За допомогою спеціально розроблених приладів та тренажерів відбувається зчитування стану м'язів тазового дна. Їх некоординована робота відображається на екрані приладу у вигляді перешкод у показі мультфільму чи погіршенні звуку тощо [12]. Завдяки спрямованим зусиллям для покращення зображення чи звуку діти вчаться координувати роботу певних груп м'язів і таким чином відбувається тренування та корекція їх роботи.

\section{ЛІТЕРАТУРА}

1. Castilla E. E. International Clearinghouse for Birth Defects Surveillance and Research. Annual Report 2011 with Data for 2009 / E. E. Castilla, L. D. Botto, M. K. Bakker. [Internet]. - 2011. - Available from: http://www.icbdsr. org/filebank/documents/ar2005/Report2011.pdf

2. Singh D. K. Families of children with spina bifida: A review / D. K. Singh // Journal of Developmental and Physical Disabilities. - 2003. - No. 15. - P. 37-54.

3. Crytzer T. M. Physical activity, exercise, and healthrelated measures of fitness in adults with spina bifida: a review of the literature / T. M. Crytzer, B. E. Dicianno, R. Kapoor // PM\&R. - 2013. - No. 5 (12). - P. 1051-1062. DOI: 10.1016/j.pmrj.2013.06.010.

4. Spina bifida outcome: a 25-year prospective / R. M. Bowman, D. G. McLone, J. A. Grant [et al.] // Pediatr. Neurosurg. - 2001. - No. 34. - P. 114-120.

5. Боярчук О. Р. Сучасні аспекти консервативної терапії нетримання сечі та збереження функції нирок у дітей із спінальним дизрафізмом / О. Р. Боярчук, К. Т. Глушко // Здоровье ребенка. - 2018. - № 6. - С. 602-608.

6. Spina Bifida / A. J. Copp, N. S. Adzick, L. S. Chitty [et al.] // Nature Reviews Disease Primers. - 2015. - No. 1. P. 15007. DOI: 10.1038/nrdp.2015.7.

7. Spina Bifida Association. Spina Bifida: a guide for medical professionals. [Internet]. - Available from: http:// www.spinabifidaassociation.org/atf/cf/\%7B85f88192-

\section{REFERENCES}

1. Castilla, E.E., Botto, L.D., Bakker, M.K. (2011). International Clearinghouse for Birth Defects Surveillance and Research. Annual Report 2011 with Data for 2009. [Internet]. Retrieved from: http://www.icbdsr.org/ filebank/documents/ar2005/Report2011.pdf

2. Singh, D.K. (2003). Families of children with Spina Bifida: A review. Journal of Developmental and Physical Disabilities, 15, 37-54.

3. Crytzer, T.M., Dicianno, B.E., \& Kapoor, R. (2013). Physical activity, exercise, and health-related measures of
Висновки. Терапія спинномозкової грижі $\epsilon$ складним та довготривалим процесом, що потребує координованої та довготривалої співпраці лікарів різних спеціальностей. Основними напрямками реабілітації дітей зі SB $є$ забезпечення фізичної активності, рухливості, контроль за вагою тіла, мінімізація нейрогенних розладів сечового міхура та кишечника, що, в свою чергу, впливає на тривалість та якість життя.

Удосконалення програм реабілітації дітей із spina bifida, створення мультидисциплінарної команди з залученням фізіотерапевта чи реабілітолога дозволить покращити ефективність терапії та, відповідно, якість життя таких пацієнтів.

Автори заявляють про відсутність конфлікту інтересів.

26e1-421e-9e30-4c0ea744a7f0\%7D/A\%20GUIDE\%20 FOR\%20MEDICAL\%20PROFESSIONALS.PDF.

8. Rehabilitation outcomes in persons with Spina Bifida: A randomized controlled trial / F. Khan, B. Amatya, L. Ng, M. Galea // Journal of rehabilitation medicine. - 2015. No. 47. - P. 734-740. DOI: 10.2340/16501977-1999

9. Spina bifida at the sacral level: more than minor gait disturbances / M. A. Schoenmakers, V. A. Gulmans, R. H. Gooskens, P. J. Helders // Clin. Rehabil. - No. 2004. No. 18. - P. 178-185.

10. Personal and environmental factors to consider when aiming to improve participation in physical activity in children with Spina Bifida: a qualitative study / M. A. Bloemen, O. Verschuren, C. van Mechelen [et al.] // BMC Neurology. - 2015. - No. 15. - P. 11. DOI:10.1186/ s12883-015-0265-9.

11. Дубина С. П. Диагностика и терапия энуреза у детей (научный обзор и личные наблюдения) / С. П. Дубина, О. С. Евтушенко, С. К. Евтушенко // Міжнародний неврологічний журнал. - 2013. - № 6 (60). - С. 114-120.

12. БОС-терапия в комплексном лечении детей с эвакуаторными нарушениями функции тазовых органов / 3. З. Соттаева, Л. Б. Меновщикова, А. И. Гуревич [и др.] // Российский вестник детской хирургии, анестезиологии и реаниматологии. - 2014. - № 4 (3). C. $46-50$.

fitness in adults with spina bifida: a review of the literature. PM\&R, 5 (12), 1051-1062. doi: 10.1016/j.pmrj.2013.06.010.

4. Bowman, R.M., McLone, D.G., Grant, J.A., Tomita, T., \& Ito, J.A. (2011). Spina bifida outcome: a 25-year prospective. Pediatr. Neurosurg., 34, 114-120.

5. Boiarchuk, O.R., \& Hlushko, K.T. (2018). Suchasni aspekty konservatyvnoi terapii netrymannia sechi ta zberezhennia funktsii nyroku ditei iz spinalnym dyzrafizmom [Modern aspects of conservative therapy of urinary incontinence and preservation of renal function in children with 
Огляди літератури, оригінальні дослідження, погляд на проблему, ювілеї spinal dysrhythmia]. Zdorovye rebenka - Health of a Child, 6, 602-608 [in Ukrainian].

6. Copp, A.J., Adzick, N.S., Chitty, L.S., Fletcher, J.M., Holmbeck, G.N., \& Shaw, G.M. (2015). Spina Bifida. Nature Reviews Disease Primers, 1, 15007. doi:10.1038/nrdp.2015.7.

7. Spina Bifida Association. Spina Bifida: a guide for medical professionals. [Internet]; Retrieved from: http:// www.spinabifidaassociation.org/atf/cF/\%7B85f8819226e1-421e-9e30-4c0ea744a7f0\%7D/A\%20GUIDE\%20 FOR\%20MEDICAL\%2OPROFESSIONALS.PDF.

8. Khan, F., Amatya, B., Ng, L., \& Galea, M. (2015). Rehabilitation outcomes in persons with Spina Bifida: A randomized controlled trial. Journal of Rehabilitation Medicine, 47, 734-740. doi: 10.2340/16501977-1999

9. Schoenmakers, M.A., Gulmans, V.A., Gooskens, R.H., \& Helders, P.J. (2004). Spina bifida at the sacral level: more than minor gait disturbances. Clin. Rehabil., 18, 178-185.

10. Bloemen, M.A., Verschuren, O., van Mechelen, C., Borst, H.E., de Leeuw, A.J., van der Hoef M. et al. (2015).

Personal and environmental factors to consider when aiming to improve participation in physical activity in children with Spina Bifida: a qualitative study. BMC Neurology, 15, 11. doi:10.1186/s12883-015-0265-9.

11. Dubina, S.P., Yevtushenko, O.S., Yevtushenko, S.K. (2013). Diagnostika i terapiya enureza u detey (nauchnyy obzor i lichniye nablyudeniya [Diagnosis and treatment of enuresis in children (scientific review and own observations)]. Mizhnarodnyi nevrolohichnyi zhurnal - International Neurological Journal, 6 (60), 114-120 [in Russian].

12. Sottayeva, Z.Z., Menovshchikova, L.B., Gurevich, A.I., Yavatkhanova, R.I., \& Abramova, A.A. (2014). BOS-terapiya $v$ kompleksnom lechenii detey s evakuatornymi narusheniyami funktsii tazovykh organov [BOS therapy in complex treatment of children with evacuatory dysfunctions of the pelvic organs]. Rossiyskiy vestnik detskoy khirurgii, anesteziologii i reanimatologii - Russian Journal of Children's Surgery, Anesthesiology and Resuscitation, 4 (3), 46-50 [in Russian].

\section{СОВРЕМЕННЫЕ АСПЕКТЫ РЕАБИЛИТАЦИИ ДЕТЕЙ СО SPINA BIFIDA}

๑О. Р. Боярчук' , Е. Т. Глушко ${ }^{1}$, Н. Н. Свирская ${ }^{2}$, В. В. Ковалев ${ }^{2}$, О. Р. Шило²

ГвУз «Тернопольский государственный медицинский университет имени И. Я. Горбачевского МОЗ Украины»'

Тернопольская областная детская клиническая больница

РЕЗЮМЕ. Спинномозговая грыжа является одним из самых распространенных врожденных пороков, при котором одновременно поражаются несколько органов и систем, что приводит к ранней и хронической недееспособности и даже смерти. Лечение и реабилитация детей со spina bifida является сложным и длительным процессом, требующим привлечения и сотрудничества врачей различных специальностей.

Целью нашей работы было проанализировать литературные данные об современных возможностях улучшения качества жизни детей з расщелиной позвоночника. Одними из самых распространенных проблем у детей с указанной патологией является ограничение или полное отсутствие подвижности, снижение кожной чувствительности и образование ран и пролежней, развитие гидроцефалии, нейрогенные расстройства мочевого пузыря и кишечника, часто сопровождающиеся недержанием мочи и испражнений; в тяжелых случаях наблюдаются когнитивные расстройства. Ограничение или отсутствие физической активности, в свою очередь, приводит к ожирению и связанным с ним осложнениям. Обеспечение способности самостоятельно передвигаться, улучшение физической активности снижает риск ожирения, улучшает социальные контакты и качество жизни. Реабилитация нейрогенного мочевого пузыря обеспечивается чистой периодической катетеризацией, проведением лечебной физкультуры и физиотерапии. Упражнения лечебной физкультуры направлены на укрепление мышц тазового дна. Разновидность физиотерапии зависит от вида нейрогенного мочевого пузыря. Одним из наиболее эффективных методов коррекции расстройств мочеиспускания считается метод биологической обратной связи. Данный метод достаточно простым способом позволяет научить ребенка координировать работу мышц тазового дна.

Выводы. Реабилитация детей co spina bifida является долговременной и многоцелевой работой, которая в значительной степени зависит от состояния ребенка и требует мультидисциплинарного ведения. Объединение усилий врачей и родителей, использование современных методов реабилитации могут улучшить качество жизни детей co spina bifida.

Поиск литературы осуществлялся с помощью баз данных PubMed и КиберЛенинка.

КЛЮЧЕВЫЕ СЛОВА: дети; spina bifida; реабилитация.

\section{MODERN ASPECTS TO REHABILITATION OF CHILDREN WITH SPINA BIFIDA} @O. R. Boyarchuk', K. T. Hlushko1, N. M. Svirska², V. V. Kovalyov², O. R. Shylo²

I. Horbachevsky Ternopil State Medical University ${ }^{1}$ Ternopil Regional Children's Hospital

SUMMARY. Spina bifida is one of the most common congenital malformations, which involves a combination of lesions of organs and systems and causes early permanent disability and even death. The treatment and rehabilitation of 
Огляди літератури, оригінальні дослідження, погляд на проблему, ювілеї

children with spina bifida is a complex and long-term process that requires the involvement and collaboration of doctors of various specialties.

The aim of the work - to analyze literary data on the current possibilities of improving the quality of life of children with spina bifida. One of the most common problems in these children is a limitation or complete lack of mobility, reduced skin sensitivity and the formation of wounds and bedsores, the development of hydrocephalus, neurogenic disorders of the bladder and bowel, often accompanied by incontinence. In severe cases, cognitive impairment is observed. Limitation or lack of physical activity leads to obesity and complications associated with it. The ability to move independently and improve physical activity reduces the risk of obesity and improves social contact and quality of life. Rehabilitation of neurogenic bladder disorders is provided by clean intermittent catheterization, physical therapy and physiotherapy. Physical therapy exercises are aimed at strengthening the pelvic floor muscles. The type of physiotherapy depends on the type of neurogenic bladder. One of the effective methods of correction of urinary disorders is the biological feedback method. It could teach a child to coordinate the work of pelvic floor muscles.

Conclusions. The rehabilitation of children with spina bifida is a long-term and multifunctional work, which depends on the child's condition and requires multidisciplinary care. Combining the efforts of doctors and parents, the use of new rehabilitation methods can improve the quality of life of children with spina bifida.

The search for literature was carried out using PubMed and CyberLeninka databases.

KEY WORDS: children; spina bifida; rehabilitation. 